\title{
SUGGESTED AMENDMENTS TO PART II. OF THE HOUSING OF THE WORKING CLASSES ACT', 1890.
}

\author{
By T. EUSTAOE HILL, M.13., 13.Sc, F.r.C., \\ County Medical Officer, Durham.
}

(FELLOW.)

7VHE Housing of the Working Classes Act, 1890, is probably the most important Sanitary Act which has been passed since the Public Health $\Lambda$ et, 1875 , in that the application of the sereral parts into which it is divided has done more to improve the dwellings and surruundings of the labouring classes, and even of the poor, than any other sanitary enactment.

The Act, as is well known, is divided into three chief parts, viz., Part I., only applicable to urbin districts and dealing with unhealthy areas by means of an improvement scheme; Part II., which applies to both urban and rural districts, and enables sanitary authorities to proceed against the owners of one or more houses which are so dangerous or injurious to the health of the occupants as to be unfit for habitation, and also to deal with obstructive buildings and small groups of dwellings by means of an important scheme; and Part III., which enables a sanitary authority to provide houses for the working classes when and where such may be necessary.

$I$ do not propose in this short paper to refer to the administration of Part I. for the clelays, difficulties and great expense invarialjly incurred by sanitary authorities who have exercised their powers under it respecting unhealthy areas have been discussed on many occasions, and I believe at some of the Congresses of this Institute. Suffice it to say that the experience of some of our large towns, in their endeavour to cleal with insanitary areas under Part I., has been an effectual damper to other towns in which large areas of dilapidated unhealthy dwellings can only bu effectually dealt with by an improvement-scheme, and that it is generally- 
admitted that Part $I$. of the Act requires to be amended so that the procedure may be simpler, the delays less vexatious, and the expense to the ratepayers greatly diminished.

Neither clo I intend to refer to Part III. of the Act, which is adoptive and in rural clistricts can only become operative with the consent of the County Council, for this part also has been the subject of many valuable papers and discussions during recent years, especially with respect to the necessity of increasing the periorl of repayment of loans sanctioned to sanitary authorities for the provision of working-class dwellings. I may state, howerel, that the procedure of this part of the Act, especially as regards rural districts, has been amended and greatly improved by the Housing of the Working Classes Act, 1900, but sreater facilities require to be granted to sanitary authorities to enable them to provide cheap and healthy houses on convenient sites for the inhalitants of orercrowded districts.

It is safe to say that the application of the provisions of Part II. has been far more general and frequent than any other part of the Act, and has been productive of most good.

Prior to the passing of the 1890 Act, proceedings for the closing of dwellings unfit for habitation had to be taken under the nuisances sections of the Public Health Acts, 187.), or the Housing of the Workingr Classes Act, 1885, and under both these Acts there were many difficulties to be overcome before an insanitary house could be closed. Byproceeding under Part II. of the Act of 1890 , there is much less difficulty in obtaining a closing order in respect to a dwelling unfit for habitation, but ten years administration of this part of the Act by the Durham County Council has revealed serious defects which in some cases cause great hardships, and may even prevent the enforcement of a closing order granted by the Justices. For the last ten years the Durham County Council has exercised its powers under Section 45 (2) of the Act, and has dealt with nealy 2,000 insanitary dwellings. By that section a County" Council has power in rural districts to call upon the Sanitary Authority to institute proceedings under the Act to close dwellings which, in the opinion of the County Council are unfit for habitation, and, if after reasonable notice, not less than one month, the County Council is of opinion that the District Council has failed to institute and properly prosecute proceedings either as regards the closing or demolition of an insanitary dwelling, or the pulling down of an obstructive building, the County Council may pass a resolution to that effect, and thereupon the powers of the District Council as respects the said dwelling-house or 
obstructive building under this part of the Act (otherwise than in respect to a scheme) shall be vested in the County Council, and if a closing order or an order for demolition, or for pulling down an obstructive building is made, and not disallowed on appeal, the expenses of the Council as respects the said dwelling-house, inclucling any compensation paid, shall be recoverable by the County Council from the District Council. In a considerable proportion of the houses scheduled by the Durham County Council as unfit for habitation, the County Council has had to exercise the powers of the Rural District Councils by defanlt, and I will shortly refer to some of the most serious difficulties enconnterel by the County Council in administering the Act, difficulties which for the most part it must be remembered have also to be met by listrict authorities who desire to close insanitary dwellings.

In the first place the definition of the word "owner" in the Act is unsatisfactory, for notices must be served and proceedings taken agrainst either the owner, as defined in the Land Clauses Acts, or against the persons holding the property on a lease or mortirage for a term of years of which at least twenty-one years hare still to rum. Proceedings camot be instituted against the agent of the owner as is permitted by the Public Health Act, 1875 , and it is of ten a very great hardship on the actual owner, who has, perhaps, let the premises on a repairing lease for a long term of years and may, therefore, not be responsible for the property falling into an insanitary state, to be called to put the property into repair or close it, because something less than twenty-one years of the lease has yet to run.

The difficulty as regards the word "owner" would be overcome if the word harl, in addition, the same meaning as in the Public IFealth Act, 1875 .

Another and much more serious defect in the Act is that when once a closing order has been obtained no further responsibility rests on the owner as to the closing of the clwelling, all subsequent proceedings to that end being directed against the tenants. The tenant must receive not less than seven days' notice from the prosecuting authority to racate the house, and if he makes default in obeying the notice he is liable to a penalty of 20 s. al day during the time he continues to occupy the house. This method of procedure often inflicts the greatest hardships on the tenant, who is usually not to blame for the insanitary condition of the dwelling, especially in overcrowded districts, where it is of ten impossible for him to find another house. The Justices making the order have power to grant a reasonable allowance, recoverable from the owner, to 
the tenant on account of his expenses in moving, but in most districts the Justices refuse to make any such allowance or to improse any fine on the owner for being in possession of insanitary property.

In practice it is of ten impossible for the prosecuting authority to get the tenant out of the house after a closing order has been obtained, for the penalties resulting from the tenant disobeying the order to quit can only be recovered by distraint, and rery frequently the personal effects are not worth distraining upon. Besicles which many authorities are averse from taking extreme measures against tenints who have committed no offence, and to whom eviction frequently means loss of employment as well as louse, owing to the imposibibility of their obtaining another house in the neighbourhood of their place of employment.

The difficulty of reetting rid of the tenants is, of course, much greater where a number of houses are ordered to be closed, especially in overcrowded districts like most of the mining districts of Durham, where it is the custom for the employers to provicle free louses for their workmen, and where, owing to the uncertain life of the collieries or works, the erection of dwellings by private enterprise is practically nil. In such cases the closing of insanitary dwellings (and I regret to say that there are still many houses not fit for habitation in the comty) would invariably mean orererowding of other houses in the district, while alpart from that, the difticulties in the way of the prusecuting anthority evicting the tenants very frequently renders the effectire antministration of the Aet impossible. The only remedy I can suggest is that the duty of removing the temants from louses urdered by the Justices to be closed should he placed on the owner, who shoulı be liable to a penalty for each day a house continues to be occupied after a date fixed by the Justices making the closing order.

It is certain that if this were done owners wonld take more care to keep their houses in a sanitary condition, and in the county of Durham, where it is the custom for the colliery-owners to provide louses for their workmen, it would impress on some owners the necessity of replacing by modern dwellings houses which nothing short of reconstruction cam make sanitary.

Another anendment of the Act which, in my opinion, is very desirable is the extension of the powers of County Councils under Section $45(2)$ of the Act to urban districts, other than boroughs. It is an undoubted fact that in many of the smaller urban districts tlere is less inclination on the part of the sanitary authorities to enforce their powers respecting houses unfit for habitation than in rural districts, owing to the fact, probably, that 
members of the Council are elected from a more restricted area, and consequently have morc common interests, and moreover are themselves not infrequently interesterl in small house-property. In such districts much grood would resuit if the County Councils had power to deal with insinitary dwellings respecting which the Urban District Councils had minde defanlt in enforcing their powers under the Inousing of the Working Classes Act.

It is also very desirable that a sanitary authority should have power to appeal to Quarter Sessions when the application for a closing order has been refused by the Justices. At present the owner is able to appeal against the order of the manistrates closing his house, but the prosecuting anthority has no appeal anginst an adverse decision which may be capricious and anainst the weight of evilence. In two instances where applications for closing orders by the Durham County Council were dismissed by the Justices, there were strong reasons for believing that the decisions, in the face of the strongest evidence as to the insanitary condition of the dwellings, were affected, in one case by private opinions formed without hearing the evilence, and in the other by local inthenoes.

From the point of riew of Cumb Councils, it is important that the Act of 15.90 should be amended by the introduction of a section which will prevent a closing oreler obtained at the instance of a County Council from being rescinded by the Justices unless clue notice lats been griven to the County Council of the application for such rescission. On more than one occasion, as a result of a certiticate being given by a Rural District Conncil, the Justices have rescinded closing order's obtained by or at the instance of the Durham founty Council without the latter's knowleclge, and the houses have subsequently been re-oceupied, although in the opinion of the County Council they have not been made properly fit for habitation. It is only reasonable that, if the County Council has been instrumental in obtaining the closing order, information should be given to that authority of any application for the rescinding of that order.

Power should also be griven to sanitary anthorities to obtain the demolition of a house permanently closed as unfit for habitation, if its remural is clesirable, even though it may not be proved to be dangerous or injurious to the lealth of the pulslic or of neighbouring tenants.

A house which has been permanently closed is unsightly and undesirable, it frequently ubstructs light and air, and in other ways may be objectionable.

The only other point to which I want to call attention has reference to the forms of notices required to be used, and which are set out in Schedules iii. and iv of the Act. 
Under Schedule iii. the form of notice and procedure is laid down in the Public Health Act, 1875, respecting nuisunces injurious to liealth, and the notice must specify the works necessary to abate the nuisance; while under Form A of Schedule iv., the notice must call upon the owner to make the dwelling fit for habitation, even though it camnot le made habitable, and it is the intention of the sanitary anthority to permanently close it. As a result of such a notice the owner not infrequently spends money in a useless endeavour to comply with its requirements, and it is very desirable that Schedule iii. should be amented to enable the sanitary authority to apply for a closing order, when the premises are so daugerous or injurious to health as to be unfit for habitation, and are incapable of being male habitable, without the necessity of calling on the owners to make them liabitable.

If that were done Form $A$ of sichedule ir., might be used with respect to premises which could be male habitable, and the notice in such casses should state the work required to be carried out to make the premises habitable.

On several occasions the Durham County Council has dawn the attention of the Local Govermment Buard to the necessity of amending Part II. of the Housing of the Working Classes Act, 1890; and the President of the Local Government Board having stated during the present session of Parliament that he proposes to introduce a Bill to amend the Housing of the Working Classes Acts, the Comty Council in May last forwarded to the Local Govermment Board and the County Councils Association the following sugrgestions prepared by the Clerk and myself for the amendment of the Acts :-

1. To make the meaning of the word "owner" the same as in the Public Health Act, 1875 .

2. To make the owner of a dwelling-house as to which a closing order has been obtained liable to continuing penalties as long as he permits it to be occupied.

3. To provide that no closing order shall be determined without notice to the Council of the Administrative County in which the dwelling is situated.

4. To give power to Sanitary Authorities to make a demolition order as to any building which is clangrerous or injurious to the health of its own inhabitants.

5. To give County Councils power to enforce the Act in urban districts other than Municipal Boroughs. 
6. Tu give a right of appeal against the dismissal of an application for a closing order.

The necessity of some, if not all, of the above amendments, having regard to effective administration of Part II. of the Act of 1890, is I think evident; and the probability of some of them being introduced into any amending Government Bill, would be greatly enlanced if the action of the Durham County Comcil were supported by the powerful influence of The Sanitary Institute acting on the recommendation of this important Conference.

Mrr. Samued Adans (Clerk to the Rural District Council of Auckland) said lhe cordially agreed with the first two of Dr. Hill's suggestions for ancendment of the Act. The first would help very materially in serving notices and getting the Act into operation, and the second would make it much casier to get an order of the just ices carrind out. But he thought that the other four sugrgestions were upen to very considerald objection. It was evident that the piper had been written frum the point of view of the county conncils. It was not well to have the county council continually interfering with the action of district councils, as was sometimes the ease. The district councils, as it was, had frequently cause of complaint of being overridden in their decisions by the county councils. The representatives of district councils were very much better able than the representatives of county councils covering a large area to determine what was best for their uwn districts, and there could be no advantage in their being subject to 1 he dictation of the county councils in such matters. Dr. Hill said that the result of the service of the notice on an owner frequently wis that he spent money in a useless endeavour to comply with the requirements of the district council. A case which would well illustrate that point had occurred at a meeting of his council the day betore. A house was reported as being unfit for habitition, and the council hand to serve notice for the necessary work to be done to make it habitable. The notice ordered to be served was one stating that the height of the rooms must be raised to ten feet, that through ventilation ind proper drainage should be provided, a new roof shonld be put on, and that the present privy and aslipit should be removed and new ones built. A member of the council asked whether it did not amount to the building of a new house, and of course it did. If the notice were not complied with, and a new house built, the liouse would be closed. Therefore he did not see any need for the suggested alteration of the law in regard to the strict operation of a closing order after the service of a notice to put the house into a habitable condition. They gave the owner the opportunity of putting the house into proper repair. If he cotuplied with the notice, well and good; if he fitiled to comply, a closing order would be obtained. With regard to the rescinding by justices of closing orders when 


\section{Suggested Amondments to Part II. of the IIousing Act, 1890.}

notices to repair had been complied with, they would notice that Dr. Hill said, "On more than one occasion, as the result of a certiticate being given by" a rural district council, the Justices rescinded clusing order's obtained by, or at the instance of, the Durham County Council without the latter's knowledge," and the suggestion was that before any action was taken for the rescinding of an order by the justices notice should be given to the county council of intention to apply. People on the spot who knew the eircumstances and knew what was necessary, might be quite satisfied that the house to which the closing order related had been put into a proper condition, but it was not enough. The county council was to receive notice, and then that borly would instruct their solicitor to make a journey to the petty sessional division where the house was situated, and the solicitor would go there, not necessarily to oppose, but to hear what was going ou. A bill would afterwards come in to the district council for $£ 5$ or $£ 6$ as the solicitor's fee and expenses. And perhaps the medical officer would go, and the clerk to the county council also, and a bill would come in to the district council in proportionate amount for their special services and expenses. It would be a means of running up costs against a district council which certainly ought to be avoided, for it was not at all a necessary step to take. The fourth surgestion made by Dr. Hill was a most serious thing for the district councils. With the press of business they now had they could not possibly find time to carefully consider the question of the demolition of buildings, and he did not think that that was a power which should be conferred upon them. Such a question should go before a judicial tribunal, and be argued out by representatives of both sides. In dealing with matters of this lind district councils were necessarily largely guided by reports from their officials, and this suggestion practically put these officials in a position which ought only to be occupied by a judicial bencl. Ils principal objection, bowever, was to the control of the county council in these matters. That wits absolutely unnecessary.

Mr. Joln Lisinsal (Glasgow) said that in Glasgow they had enforced the provisions of Part $\cong$ of the Act, and they had not experienced the difficulties which seemed to have beset the operation of the Act in some other parts of the country. He had notieed that one of the difficulties thiat Dr. Hill referred to was the restricted meaning of the word "owner." This was an imperial statute, applicable to Scotland as well as to Englind, but in Glasgow they had not had this difficulty, beciuse in the definition Act they were referred back to the Public Health Act, and in the Scottish Public Health Act the word "owner," inter alia, included the person actually in receipt of the rent, and tor the purposes of the Act they got at the factor and they regarded him as the owner. They got him on the spot, and so were relieved of the difficulty which arose in some cases of having to prove who the owners were. In many cises the owners were beneficiaries of old trust-estates, and they might be in all parts of the world. Ile did not, however, know whetber the definition of "owner" in the English 
Public Health Act was as broad as that in the Scottish Act. Another point of diffieulty in England seemed to be in regard to the procedure which might be taken against the tenants for compelling them to leave a house after the closing order had been pronounced, and it did seen a little strange that the proceedings should be brought against the tenants alone and not against the owner. But in that matter also they had not the difficulty to contend with in Glasgow, because there was a provision, referred to in the paper, that any compensation which was to be payable to the tenant by the local authoritics was recoverable by the local authorities from the ownel, and not in any one of the cases that he had prosecuted had any difficulty arisen. And the reason was this, that the owner felt he was sufficiently punished by the closure in the first instance and the demolition afterwards of his property, without incurring any risk of recouping the local authority for compensation to the tenants. Therefore he arranged with his tenants to have them removed, if need be, by making an application to the Court for a summary ejectment of the tenant upon giving him notice some ten days, being a third of the period of his lense or tenancy, the tenants being in the majority of cases monthly tenants. But a point of greater surprise to him as to the practice of the Courts in England was the following sentences: "On more than one occasion, as a result of a certificate being given by a rural district council, the justices have rescinded a closing order obtained by, or at the instance of, the Durham County Council without the latter's knowledge, and the houses have subsequently been re-occupied." He could not understand that. He could not imagine that any Court, ispecially a Court of Appeal, as this Court practically was, would rescind any judgment of a prior court without intimation being given to the representatives of the local authority, and without their being heard. The practice in the eity of Glasgow was where a nuisance existing in a house was such that the remedying of it conld accomplish the desires and wishes of the local authority, then they simply took procedure under the Public Health Act with a view of laving the state of matters complained of remedied. And in the event of fiulure to satisfy the order of the Court, there was a subsequent section which entitled him to ask the Court to prohibit the use of the dwellinghouse until the order of the Court had been carried out. But if the state of matters in the house was such that no immediate remedy would meet the riews of the local authority, then they had power, under a local act, on a certifiente granted by the medical officer of health, the sanitary inspector, and the master of works (who was known in England as the borough surveyor), to take proceedings for the immediate closure of any such houses. The granting of that certiticate raised a presumption against the house, and they gave notice to the owner to appear, not before a court of law, but before their committee of health, which was a committee delegated with powers from the corporation or local autbority, and unless cause was shown to the contrary a closing order was pronounced, with the right of appeal within some five days to the Sheriff, whose position was somewhat like to that of the county court judge in England. 


\section{- 586 Suggested Amendments to Part II. of the IIousing Act, 1890.}

Under that power they had closed up hundreds of houses in the city of Glasgow. There was a provision by which afterwards, when the house had been put into order, the owner could come back to the committee of health and ask for the order being rescinded, and that was done in some instances; but otherwise the house remained closed, or was demolished, or its use was changed and the premises occupied for business purposes. Supplementary to that provision they obtained, in an Act of 1900 (a Building Regulations Act), powers whereby they could demolish these houses instead of under the earlier locul Act, where proceedings liad not been taken by the owner to liave them rendered fit for human habitation, or where they continued to be a menace to the health of the people in the adjoining property. Further north they were very radical and drastic, and where they met a state of matters such as was described in the paper the remedy must be drastic and must be applied without any hesitation, and they we'e not usually guilty of any very great hesitation when such a state of matters was demonstrated to the committee. But if they were not satisfied even with all tbese methods of procedure, they proceeded under the Housing of the Working Classes Act. They had never availed themselves of Part I., because in that city they had local Acts, City Improvement Acts, which enabled them to deal with large areas. I3ut as it had been represented to the Corporation by the medical oflicer that under that Act they should direct their at tention to the matter of back lands, that was tenements reared up in what was originally intended to be the back court or yard of the front dwelling-houses, they had a special committee appointed to supervise all these back tenements in the city. They had selected cases where the hardship would be at the minimum, and taken all those properties, which were very numerous in Glasgow, where the back land was owned by the same proprietor as the front property; and when the owner argued it a case of hardship to demolish without compensation, as he invariably did, the answer was given that be was most to blame in this respect, that he had utilised as a situ for another tenement what was intended primarily to be the back yard and breatbing space of the front tenement, and in no one instance had lis plea for sympathy and compensation been sustained. He did not say laad not been sustained by the local authority, because from them the owner never looked for much sympathy, but the plea bad never been sustained in a court of law. Under that procedure they wer. bound to go in the first instance to the Sheriff for a closing order, and then an order of demolition was pronounced by the local authority through its committee, with a right of appeal back again to the Sherift. They selected these cases and got their certificates under Section 32, which said that the house was unfit for human habitation; and, having satisfied the Court upon that point, they served upon the owner a notice to put it in order. They knew that the condition of that house, and its situation and surroundings, were such that he could nut carry unt the requirements of that statutory notice; but that did not bother them at all, it rather assisted and influenced them in their 
endeavour to get rid of these pligue-spots in the bilk courts, and, having got their closing order, they pronounced the demolition-order, and though the owner appealed to the Sheriff, they proved the two points which were recluired for the successful operation of Sections 32, 33, and 34: firstly, that the house in itself was uninhabitable, and secondly, that through its contiguity to adjoining property, it never conld be made habitable according to their standard; the statutory standard of free space for air and ventilation. The first case they tried was fought fiercely, and in that case, as in subsequent cases, the argument was used that this was the only estate available for the support of some spinster lady. They heard that argument in almost every case; it was always either a widow or a spinster; but they got their demolition-order all the same, and brought it home to the Court that there was no room for sympathy in the case, because the house had occupied a site which never should have been occupied, and the occupation of which deprived the tenants of the front property of the benefit of that back court for air, ventilation, washing-house, ashpit, and watercloset accommodation. The Court in these cases granted the order, and the property was taken down, the front property thereby getting the air and rentilation it was entitled to, and the rents of the front property went up. The advantage of taking procedure in a case of that lind against the owner of both propertics was thit thereby they aroided questions between different lindlords, and of course, where the owner was the same in both instances, the (lement of compensation did not arise. They had followed out from 1890 until to-day the provisions of Sections 32 to 34 , and under these provisions they lad cleared out a number of these back lands in the City of Glasgow. It might be that it was peculiar, especially to Glasgow, that the owner was the same, but they had selected these cases for that retson, and in the list eight cases, dealing with property whose rental in some cases was over $£ 100$ il year, they had taken proceedings and, consequent on the decision of the first case which he had referred to, prior to the new orders in these eight cases, the owners of the latter had come and said that rither than fight these cases and run the risk of being found liable in the Court expenses, they would pull down the property. This was done at the last term of Whitsun and the Corporation had had no more difficulty. They had not started any case where compensation was exigible, and they Lad successfully avoided the application of Section 3s, which merely referred to an "obstructive" building which in itself might be fit for liuman habitation. Their main contention all through had been that the house ras unfit and could never be made fit for human habitation for the reason that it was surrounded at the sides by property belonging to other people, but mainly. at the front by property belonging to the same owner. The Glasgow Corporation had in their Building Regulations Act a provision which assisted them to a great extent by stipulating that there could be no sleeping apartment used which had not arailable to it as free space one half of the height from the floor to the ceiling of the particular house : and they caught must of the landlords 
of old and dilapidated property upon that point, beause the front of the back building was so near to the back of the front building that the houses could not possibly get that space. In the last case fonght against the Glasgow Corporation the objection had been taken that the medieal officer in his representation did not state what was required to male the house fit for human habitation. On bebalf of the medical officer he declined to state it, and his argument was this: that, while under ordinary circumstances under the Public 1Tealth Act and the Local Acts. when an owner was called upon to remedy a certain state of matters they were bound to give a description. when dealing with the Housing of the Morking Classes lit they were not bound to do anything of the kind, for this reason: that in the schedule annexed to the Act there was a statutory form of notice which did not providi for details, and the schedule, being part of the Act of Parliannent, must be followed out literally, and they maintained successfully before the Conrt that, having taken the statutory form contained in Schedule $A$ of the Act, it would have been illegal on their part to have gone beyond it and given details: and the Court sustained that contention and granted the elosing order, and the property is now dow.

Dr. W. Buldur (Willesden) said he sympathised with the objection which Dr. Hill had raised as to having to specily, in applying for a closing order, what should be done in wrder to milke the propurty habitable. He happened just now to have to deal with some promises nude. section :3:2, and he was in the anomalous position of haring to prescribe what was repuired to put the houses into habitable condition under circumstances where it was impossible to carry the prescription out. He was deilling with honses which happened to he in precisely the condition deserihed by lle last speaker, these latving been built upon the hack area of surrounding houves. They were not the property of one owner, and they were in the most awfinl condition which it wils possible to imagine houses used for human habitation to be in. He had purposed specifying what was requisite to put these in to baljitable condition. knowing all the time that it was altogether impossible that these requirements could be carried out; to have to proscribe for air-space, for instance. where there was not air-space available. But he was advised by the relerk to the local anthority that if he did prescribe all that was necessary he would lose his ease. Therefore he had to content himself with a prescription which was not adequate to the case. He had to prescribe what was best for the houses to malie them habitable, and yet he had to fall short of what he knew was necessary to make them habitable so that he could get the order. And it was conceivable that the ownel would carry out lis prescription, and in the end would har. produced an insanitary set of houses in place of some which were rather worse at present. and then make an application for the rescinding of the closing order, and he would be left, as a result of the operation of this Act, with houses which, although considerable sums of money had been expended on them to make them sinitary, remained in the end utterly insanitary. For such reasons as these he had great pleasure in endorsing the recommendit- 
tions of Dr. Hill that the prescription should be omitted from the Housing of the Worling Classes Act.

Dr. Bоoввтег (Nottingham) said that, in dealing with insanitary dwellings under Part 2 of the Act of 1890 in urban districts, the responsible officers of such districts adopted slightly varying procedure, on account of the somewhat different interpretations of the $\Lambda$ ct given by their severul legal advisers. $A$ fair idea of the range of variation which commonly occurred might, he thought, be gathered from different opinions expressed by the contributors to the current discussion. Their own procedure in Nottingham, when citing an owner before the Health Committee, was to lurnish this person with an architect's specification of the work required to render the house or houses complained of fit for habitation. Such a specification very often of course amounted to a raluctio ad absurdum. The owner was perhaps called upon to achieve the impossible. He had possibly to raise all the flours of a bouse, the basement of which was considerably below the parement of the street in which it stood. Or again, he might be called upon to provide through ventilation, ventilation which would necessarily involve the destruction of back-to-back bouses. The ownership question was not commonly the main difficulty in county boroughs and other urban districts, but the magistrates who had to consider the applications for closing orders were often a very serious difliculty, especially in cases where there was often no appeal from their decision. He would give an example. A short time back he had condemned, seriatim, a large number of houses (between forty and filty) in one district. The entire health committee of the eity, and many other people afterwards, also examined the houses, and unanimously concurred in the condemnation. When the application for closing orders came before the locill bencl, the magistrates first asked the rentals; they were told from 1s. to 2s. 6d. per week. They then inquired whether the inmates could afford to pay more; the defendint counsel replied in the negative. They then asked whether there were any other houses in the city of so low a rental, and were told there probably were not. They finally said they would be no parties to a scheme for turning hitherto-self-supporting people into the workhouse, or worse, and dismissed the applications en blor. It was often useful to put examples of this lind before inexperienced people of philanthropic bent, to afford them an idea of some of the possible difliculties of locil authorities in endeavouring to deal with insanitary property. There was one very serious difliculty, due to an intrinsic defect in the Act of 1890 , wbich was encountered after a closing order had been obtained. It was this: An order for demolition of insanitary houses could not be made unless such houses could be shown to be a nuisance to the neigbbourhood. As it was commonly impossible to show that an empty louse carefully closed up was a nuisance, within the meaning of this term under the Public Health Act, the empty house was frequently left standing indefinitely. It was, indeed, actually part of the routine duty of officers of the ITealth Department Vol. xxir. Pan'iv. 
to see that the louses did not lapse into such a condition, in some respects at least, as to justify the order for their demolition.

Dr. H. Maxley (West Bromwich) said that the speeches which had been made had amply demonstrated the need for amendment of the Act. In regard to the question of prescription, he had always maintained that th'y were not bound, as in the Derby case, to put forward a specification in all these cases, but his town clerk had always held that he must. He would weleome any amendment of the law which would sweep away any doubt as to such a prescription being necessary. In rogard to the appeal to Quarter Sessions, he was rather inclined to think that local authorities would get very little lielp from them, because, unless they were appealing to Urloan Quarter Sessions, they would simply be appealing from one set of magistrates to their own colleagues; and it was very doubtful always whether they could get a quarter sessions bench to upset the decision of three or four of their own colleagues. It was not like appealing to the Borough Quarter Sessions where there was a Recorder. In regard to the demolition question, most of them would remember the great difficulty which Dr. Newsholme had at Brighton. It was difficult to prove that the closed house was a nuisance, although the area round that louse might be a Tery great nuisance. It was often the haunt of tramps, and the depository of fæcal matter for the neighbourhood. It seemed highly necessiary that they should have greater facilities for dealing with these insanitary dwellings, as in Glasgow.

Dr. T. Eustace Hibl (Durham), in replying on the discussion, said that with one exception the suggestions in his paper had not been adversely criticised to any serious extent. He was glad to see that even $\mathrm{Mr}$. Adams had agreed to two of the most important suggestions, numbers 1 and 2. Except in one or two particulars his paper applied to all sanitary authorities who were endeavouring to put the Act into force. The only suggestions separately affecting County Councils were numbers 3 and 5. Mr. Adams had asked why rural authorities should be put under the thumb of the County Council when urban authorities were not. His answer to that was that he suggested that urban authorities also should be put under the thumb of the County Councils where it was conclusively shown that urban authorities neglected their duties under this Act. It was undoubtedly a fact that the application of this Act was gross'y neglected in very many rural and small urban districts. Although Mr. Adams had held that no alteration of the law was necessary with regard to the serving of the notice he thought that that point lad been well discussed and it was not necessary for him then to say anything more respecting it. 'The case quoted by Mr. Adams, as having been before one of the lucal bodies, on the previous day, was a proof of the necessity for some amendment with regard to Schedules 3 and 4 , and that gentleman's argument did not affect what he was urging, namely, that Schedules 3 and 4 should be amended so that the former would be used will 
respect to a house which could not be made habitable, and Form A of Schedule 4 would then only be used in cases where the property could be made habitable, and the requirements necessary to make the house habitable would bave to be stated in the notice. If that were done the needs of all clisses of houses would be met. He thouglit $\mathrm{Mr}$. Adams had rather raised a bogey when be spoke of the increased cost to local authorities if notice had to be given to the County Council before the order for closing was rescinded. He could assure lim that there was no ground for such a fear, and he beld most strungly that the order for rescission should not be granted without notice being given to the County Council. On account of the difficulties which the Durham County Council hal had, they had recently requested every clerk to the justice's to infurm the County Council directly of any application for rescission of closing order's, and in two or three cases the clerlis to justices had given them that information. In two cisses lie laad himself seen the property, and in one case, where he was satisfied that the houses had not been made habitable, the owner was adrised not to mike his applicition, and in the other case certain other alterations were made before the closing order was rescinded. Mr. Adams oljjection was unly a bogey, and in practice would not be substantiated. In regard to Mr. Lindsay's observations it appeared prolsable that in England local authorities could proceed under Schedule 3 of the Housing of the Working Classes Act and could serve notice on the agent of the owner, corresponding in Englind to the factor in Scotland ; but if they did that they had to prove that the property was injurious to liealth. Sometimes this was diflicult, and undoubtedly the sanitary authority in its notice under Schedule 3 hald to prescribe what repairs should be carried out, otherwise the notice would be bad. A point not impressed sufficiently by the paper was that the County Council, if they took action by default under Section 45 of the Act, could only proceed under Schedule 4 , and they had therefore to serve the notice on the owner who must be the owner as defined by the Act; and it was in that respect particularly that he thought that the Act should be ainended. He quite agreed as to the great difficulty at present with regard to the serving of the notice requiring an owner to make the louse habitable, even though the house could not be made fit for habitation. The ruling of the clerk to his County Council was that in the notice all they had to do was to require the owner to male the house labitable and that no specification was necessary, but even in that case there was the objection that before the nutice had expired the owner would probably endearour to inprove its condition, although it was impossible to make it babitable, and would therefore be going to needless expense, because, after all, the house would be closed. There was need for amendment in that case also. He was rather sorry to hear of Dr. Boobbyer's experience with the magistrates, but there was no doubt that the difficulty with the justices was a very real one and very lard to get over. But whilst he admitted that there was a natural objection on the part of the magistrates at Quarter Sessions to reverse the decision of their collengues, he thought that in practice, where it could be proved that the decision of the Petty 


\section{Suggestcd Amendments to Purt II. of the Housing Act, 1890.}

Sessional Court was against the weight of evidence, there would be no difficulty in getting the decision reversed; and he therufore boped that his suggested amendment as to appeal to Quarter Sessions would be included in any recommendations which that Conference might make for the amendment of the Act. He moved that the amendments suggested in the paper be approved by that Conference of Municipal Representatives and referred to the Council of the Institute for consideration and report.

Dr. ManLey seconded the resolution.

Couscillon Jowers (Bradford) said that their present manner of proceeding appeared to him to be somewhat defective, in that these recommendations might go forth to the public as the only amendments required in the opinion of that Conference when there might be other amendments which were equally required, but were not at present known to the Conference. But he supposed there was no lielp for it but to go on as they wre doing.

Mr. Aduss said that if these suggestions of Dr. Hill's were to go forward as recommendations to the Council, he wished to move an amendment in relation to Clause 5 . In view of the evident desire of the Conference that certain pourer: of control should be vested in the County Councils, le wished to linit the exercise of sucb powers to both urban and rural districts containing a less population than 50,000. His amendment was: "That no power should be conferred upon County Councils to deal with an urban district with a population of 50,000 or with a rumal district of such a population."

Codroingon J. Kavaragil (Bishop Auckland) seconded the amendment.

Audermas Imme (South Shields) said that this amendment bronght up fresh matter for discussion. He held that the County Council was a great muisince to the urban districts. In the midst of the Durham County Council's area was in urban district containing 50,000 inhabitants. They were hedged in, and the County Council took care that the urloan district did not extend. The County Council would probably, by their waut of carefiul sanitation in the district immediately adjoining that urban district, make it impossible for the part of the urban district nearest it to become a healthy district. How many town had recently been applying for the extension of their buundaries? Under this Housing of the Working Classes Act in a large congested district, such as South Shields, they were constantly closing houses under a magistrate's order, and sometimes they got a demolition-order, but it was usually voluntary on the part of the owner because they had no power to demolish a liouse unless it was in a dangerous condition, in which ease it became the duty of the city engineer to destroy it. What were they to do with the population that they were constantly removing? The proper remedy, of course, was to acquire laud outside, but if they acquired land outside of their own area they were losing ratable valur, and it was like a shopkecper advising lis customers to go elsewhere. What a serusib!c rating atuhority would do under such circumstances was to ask for 
power to extend their area and to take in some of the agricultural land outside. Then in such a case the County Council intimated that it would oppose any such application. Only a year or two ago the Sout li Slields Council applied for an extension of their boundaries, enabling them to take in a lot of unoccupied agricultural land in the immediate vicinity. It was contemplated to run out trams to this district; and, of course, without the modern facilities of trams, it would be a great hardship to take the working class population outside the town in this way. The County Council opposed them and the Rural District Council opposed them, and instrad of getting the land they needed they got an insanitary area, densely populated, which they did not want. He would like to add to the resolution sometluing like this:- "As the difficulty is mosily confined to densely populated urban districts. County Councils should be rerommended to give every facility for these urban districts to extend their boundaries, and thus provide room for spreading out their pupulation."

Mr. T. A. (xur (Bradford) again urged that there was a goul deal in the way of useful recommendations: which should be dealt with in addition to the matters included in Dr. Hill's suggestions, and he suggested that they should content themsilves with passing a general resolution to the effect that the different authorities represented at that Conference should send in to the Council of the Institute particulars of any amendments which they thought to be necessary for the proper working of the Act, and that the Council of the Institute should take all these sugrgestions into consideration and make representations to the Government in accordance therewith. If that were done he thought som practical result would have been arrived at as a consequence of that Conference.

Mr. B. Hepwontu (Heckmondwike) said he thought there were Urban District Councils with only 10,000 population which had quite as much intelligence, so far as the members of the Councils were concerned, as those with 50,000 population had. It seemed to him that they were maling a way for swallowing up all smaller District Councils in England, horrerer well they managed thrir business. He was entirely opjosed to the County Councils having the porrer which was suggested in clause $\overline{5}$. He thought that the County Councils had more to do already than they could do well. The County Council seemed to be simply a huge body for spending money, and the less the Urban District Councils bad to do with the County Council the better it would be for the people. He was speaking as a district councillor and a guardian.

Mr. Adass's amendment wais then put and defeated.

Mr. J. Cornigix (Ince) moved the omission of clinuse 5 .

Mr. W. Drsox (Kettering) seconded the amendment. He said that urban districts were quite capable of dealing with their own business. It seemed to him rather ridiculous that the powers should be handed over to the County Council in regard to a place like Kettering with a population of. 30,000, when 


\section{Suggested Amentments to Part 1I. of the IIousing act, 1890.}

they had three boroughs in the county with a population of less than 5,000 each which would be at liberty to control their own affairs.

Alderaras Imrif (South Shields) expressed a hope that the Conference would not pass that amendment, for it would not suit the Northumberland and Durham districts at all. They would not get any improvement in the sanitation of the county districts if they passed that amendment, because the people in most of the rural districts were under the thumb of the landowner or the mineowner, and in either case it would be practically impossible for sanitation to be carried on and improved, and they would be no better off than they were before the times of medical officers of health and the larger duties assigned to County Councils.

The amendment was put, and defeated by 17 rotes to 10 .

Mr. Aldars then moved an amendment, "that the Council be asked to take such steps as are necessary to release rural districts with a population of 50,000 from the control of the County Council." He pointed out that many municipal boroughs with less population than that were free from County Council control, and said there was no reason why rural districts with that large population should not be in the same position.

The amendment was seconded, and, upon being put, was defeated.

Mr. T. A. Grr then mored, "that the Comncil of The Sanitary Institute be requested to ascertain the rrcommendations of the large towns of the country with regard to desirable amendments of the Housing of the Worlking Classes Act."

Dr. T. Eustace Hir. said he would accept that as an addendum to his resolution, but he wished to point out that if too much time was taken up in doing what was suggested the influevee of the Congress would be lost. 'The Bill would come before Pariiameut and be passed during that Session, and it would probably be a long time before thero would be any other amending Bill.

Mr. Apaxs asked why the inquiry should be limited to the large towns, and said the bulk of the population was nut in the large towns. Would Mr. Guy mind specifying that the opinions should be asked of Boroughs, and Rural District, and Urban District Councils.

Mr. Gry said he sbould prefer to leave it to the discretion of the Cuuncil as to whom they should make the incuiries from.

The proposed addendum was then put to the meeting and carried, and the recommendations contained in Dr. Hill's paper were carried as a substantive resolution.

Note.-Resolutions passed at meetings of the Institute can only be in the form of recommendations to the Council, to whom they must be sulmitted for consideration and approved before they ean be considered as the oflicial opinion. of the Institute.

Totes of the decisions of the Council on the resolutions are given at p. 855 . 